\title{
The ups and downs of HIV-I gene expression
} Rosemary E Kiernan

\author{
Address: Laboratoire de la Regulation des Genes, Institut de Genetique Humaine, Montpellier, France \\ from Frontiers of Retrovirology: Complex retroviruses, retroelements and their hosts \\ Montpellier, France. 21-23 September 2009 \\ Published: 24 September 2009 \\ Retrovirology 2009, 6(Suppl 2):III doi:10.II86/I742-4690-6-S2-III
}

This abstract is available from: http://www.retrovirology.com/content/6/S2/II I

(c) 2009 Kiernan; licensee BioMed Central Ltd.

Following infection, Human Immunodeficiency Virus type 1 (HIV-1) becomes stably integrated into the genome of the host cell. It depends, therefore, on host cell factors to regulate its transcriptional output, both positively and negatively. HIV-1 transcriptional silencing requires chromatin remodelling and transcriptional repressor complexes, as well as heterochromatin formation at the integrated provirus. An important feature of silenced proviruses is their ability to be re-activated by either the viral transcription factor, Tat, or environmental stimuli. Activation of transcription is also controlled by numerous host cell factors. We have identified novel mechanisms of transcriptional activation and repression that depend on cellular macromolecular complexes such as proteasome and nuclear exosome. I will discuss recent developments in understanding the mechanisms by which these complexes control HIV-1 transcription, and the implications for viral latency. 